Editorial

\title{
Urban Planning and the Smart City: Projects, Practices and Politics
}

\author{
Andrew Karvonen ${ }^{1, *}$, Matthew Cook $^{2}$ and Håvard Haarstad ${ }^{3,4}$ \\ ${ }^{1}$ Department of Urban Planning and Environment, KTH Royal Institute of Technology, 10044 Stockholm, Sweden; \\ E-Mail: apkar@kth.se \\ ${ }^{2}$ School of Engineering and Innovation, Open University, Milton Keynes, MK7 6AA, UK; E-Mail: matthew.cook@open.ac.uk \\ ${ }^{3}$ Centre for Climate and Energy Transformation, Faculty of Social Sciences, University of Bergen, 5020 Bergen, Norway; \\ E-Mail: havard.haarstad@uib.no \\ ${ }^{4}$ Department of Geography, Faculty of Social Sciences, University of Bergen, 5020 Bergen, Norway
}

* Corresponding author

Submitted: 19 February 2020 | Published: 13 March 2020

\begin{abstract}
Today's smart city agendas are the latest iteration of urban sociotechnical innovation. Their aim is to use information and communication technologies (ICT) to improve the economic and environmental performance of cities while hopefully providing a better quality of life for residents. Urban planners have a long-standing tradition of aligning technological innovation with the built environment and residents but have been only peripherally engaged in smart cities debates to date. However, this situation is beginning to change as iconic, one-of-a-kind smart projects are giving way to the 'actually existing' smart city and ICT interventions are emerging as ubiquitous features of twenty-first century cities. The aim of this thematic issue is to explore the various ways that smart cities are influencing and being influenced by urban planning. The articles provide empirical evidence of how urban planners are engaging with processes of smart urbanisation through projects, practices, and politics. They reveal the profound and lasting influence of digitalisation on urban planning and the multiple opportunities for urban planners to serve as champions and drivers of the smart city.
\end{abstract}

\section{Keywords}

digitalisation; innovation; planners; smart cities; urban planning

Issue

This editorial is part of the issue "Urban Planning and the Smart City: Projects, Practices and Politics" edited by Andrew Karvonen (KTH Royal Institute of Technology, Sweden), Matthew Cook (Open University, UK) and Håvard Haarstad (University of Bergen, Norway).

(C) 2020 by the authors; licensee Cogitatio (Lisbon, Portugal). This article is licensed under a Creative Commons Attribution 4.0 International License (CC BY).

Urban planning practices have always been closely intertwined with technological development. From the rise of nineteenth century infrastructure networks to the introduction of automobiles, streetlights, spatial analysis tools, personal computers, and the World Wide Web, planners have been tasked with mediating and aligning society and technology to produce contemporary cities (Coutard \& Rutherford, 2015; Graham, 2001; Graham \& Marvin, 1999; Kurath, Marskamp, Paulos, \& Ruegg, 2018; Rutherford, 2020). Today's smart city agendas embody the latest iteration of sociotechnical innovation with the promise of using information and communication technologies (ICT) to improve the economic and environmen- tal performance of cities while hopefully providing a better quality of life for residents.

The rise of smart cities has catalysed numerous debates around the heightened role of technology firms in the management of collective urban services (Coletta, Evans, Heaphy, \& Kitchin, 2019; Karvonen, Cugurullo, \& Caprotti, 2019), the importance of global competition in attracting businesses and residents (Hollands, 2015; Söderström, Paasche, \& Klauser, 2014), and the dangers of privatising infrastructure networks (Marvin, LuqueAyala, \& McFarlane, 2015; Viitanen \& Kingston, 2014). At the same time, the influence of urban planners has been surprisingly muted, despite the fact that smart city agen- 
das are "challenging longstanding principles and practices of planning" (Späth \& Knieling, 2020, p. 3). Indeed, the smart city competes with (and sometimes overshadows) sustainable urban development agendas (Evans et al., 2019; Haarstad, 2017; Parks \& Rohracher, 2019; Yigitcanlar et al., 2019) and tends to promote universal standards that reinforce a "reductionist mode of urban planning and development" (Joss, Cook, \& Dayot, 2017, p. 31). Cowley and Caprotti (2019) go so far as to characterise the smart city as a form of 'anti-planning' that is rapidly replacing the normative foundations of the profession with notions of efficiency, standardisation, and corporate control. These critiques raise significant questions about how planners and incumbent planning practices are currently contributing to smart cities and more importantly, how they should contribute in the coming years. In short, what is the role of urban planning in the twenty-first century smart city?

The aim of this thematic issue is to explore the various ways that smart cities are influencing and being influenced by urban planning agendas and actions. The contributors draw on theories and perspectives from urban planning, human geography, science and technology studies, political science, public policy, and sustainability science to interrogate the social and material aspects of contemporary smart city activities. The emphasis on urban planning situates smart urbanisation and the enthusiasm for digitalisation in the longer, multi-faceted trajectory of urban change. Specifically, the authors explore how smart urbanisation is simultaneously ignoring, superseding, and reshaping urban planning practices while also highlighting the ways that urban planners are intervening in these activities.

The first two articles in the collection emphasise the political aspects of smart cities and urban planning through case studies of the globally renowned and highly controversial Quayside development in Toronto. Constance Carr and Markus Hesse (2020) adopt a postpolitical perspective to interpret the actions by Sidewalk Labs (a subsidiary of Alphabet and sister company to Google) in subverting and dominating land use development practices to prioritise private interests over the public good. They emphasise the potential negative impacts of the project on public services of transportation and housing as well as the labour market and illustrate the multiple ways that public authorities are increasingly vulnerable to corporate influence. Kevin Morgan and Brian Webb (2020) compare and contrast the technocentric and citizen-centric narratives that have emerged around the Quayside development and note a distinct lack of engagement by urban planners in mediating these frequently opposing agendas. However, recent citizen-led protests have forced the public authority to rethink its role and this has the potential to steer the development in new directions. Both articles highlight the intense conflicts that arise when sociotechnical innovation is fused with future urban land use planning.
A common characteristic of many smart cities programmes and projects is the reliance on experimentation to test new technologies in situ (Cook, Horne, Potter, \& Valdez, 2018; Evans, Karvonen, \& Raven, 2016; Karvonen, 2018). Lina Berglund-Snodgrass and Dalia Mukhtar-Landgren (2020) draw on neo-institutional theory to compare and contrast how the traditional 'public sector' logic of urban planning is influenced by an emerging 'experimental logic' that they characterise as 'testbed planning.' They argue that there is a clear disconnect between experimental activities and long-term planning practices and raise questions about how the knowledge generated in experiments can inform the longterm planning and development trajectories of cities. Katharina Lange and Jörg Knieling (2020) also examine the role of experiments as they relate to urban planning with a specific focus on how externally funded experiments are integrated into local development agendas. The authors use a multi-level governance framework to examine how Horizon 2020 grant funding from the European Commission was used to create an experimental low-carbon smart district in Hamburg. Their research shows how urban planners translate and rework international smart aspirations to align with long-term, context-specific development dynamics.

The final two articles of the thematic issue focus on the influence of digitalisation on urban planning. Ashlin Lee, Adrian Mackenzie, Gavin Smith, and Paul Box (2020) summarise the rise of platform urbanism to illustrate how the digitalisation of collective urban services creates new modes of governance. Their survey of urban data projects around the world reveals the dominance of corporate actors and the promotion of standardised digital practices that lock customers into specific modes of service provision while locking out competitors and alternative approaches. At the same time, they identify multiple examples of how public authorities can design and manage platform services to support community and social groups rather than corporate shareholders. Zipan Cai, Vladimir Cvetkovic, and Jessica Page (2020) examine digitalisation from a different perspective by focusing on land use development dynamics in the contemporary city. The authors use a 'fuzzy' statistical approach to develop quantitative indicators that reveal the influence of digitalisation on the broader industrial, economic, and social sectors. Their findings suggest the need to focus not only on discrete smart districts and programmes, but also on the more pervasive influence of digitalisation on all facets of urban life.

As a whole, the articles illustrate how the projects, practices, and politics of smart urbanisation are influencing and being influenced by urban planning activities and actions. Planning smart cities involves the development and application of digital tools and systems that can celebrate the diverse, distinctive, and inherently messy character of specific locales rather than support the drive towards more sanitised, generic, and onedimensional global cities (Aurigi \& Odendaal, 2020; Kaika, 
2017). Moreover, smart cities are deeply influenced by 'glocal' practices of knowledge politics and urban planners need to engage with and influence those global knowledge networks that are shaping local urban development (Davidson, Coenen, Acuto, \& Gleeson, 2019; Wathne \& Haarstad, 2020). Finally, there is a need to recognise smart cities not as a technological agenda but rather as a sociotechnical agenda that involves fundamental social, political, and cultural changes (Evans et al., 2019; Glasmeier \& Christopherson, 2015; Karvonen et al., 2019). Planners are ideally positioned to identify and shape the relations between technological innovation and society in smart cities by forwarding collective interests and serving as guardians of the public good.

Today's smart technologies provide urban actors with the ability to generate and share data to inform existing decision-making processes and to hopefully make cities more sustainable, resilient, and liveable. In the not-sodistant future, more sophisticated applications of machine learning and artificial intelligence will have profound and far-reaching influence on urban metabolisms and human life. It is tempting for one to be pessimistic about the rise of the smart city and the increasing influence of big technology corporations on the intimate lives of urban residents. However, the evidence presented in this thematic issue suggests that who and what controls the smart city is still up for debate. Ultimately, this serves as a clarion call for urban planners to fully engage the smart city, serving not only as partners and collaborators in public-private, triple and quadruple helix partnerships, but also as champions for directing technological innovation towards the improvement of urban governance and collective services while always serving the public at large. Planners and planning practices have been bypassed by the smart city agenda for too long; it is time for this to change.

\section{Conflict of Interests}

The authors declare no conflict of interests.

\section{References}

Aurigi, A., \& Odendaal, N. (2020). From "smart in the box" to "smart in the city": Rethinking the socially sustainable smart city in context. Journal of Urban Technology. Advance online publication. https://doi.org/ 10.1080/10630732.2019.1704203

Berglund-Snodgrass, L., \& Mukhtar-Landgren, D. (2020). Conceptualizing testbed planning: Urban planning in the intersection between experimental and public sector logics. Urban Planning, 8(1), 96-106.

Cai, Z., \& Cvetkovic, V., \& Page, J. (2020). Title pending final version. Urban Planning, 8(1), 129-139.

Carr, C., \& Hesse, M. (2020). When Alphabet Inc. plans Toronto's Waterfront: New post-political modes of urban governance. Urban Planning, 8(1), 69-83.

Coletta, C., Evans, L., Heaphy, L., \& Kitchin, R. (Eds.).
(2019). Creating smart cities. London: Routledge.

Cook, M., Horne, R., Potter, S., \& Valdez, A. M. (2018). Exploring the epistemic politics of urban niche experiments. In J. S. Jensen, M. Cashmore, \& P. Späth, (Eds.), The politics of urban sustainability transitions (pp. 125-147). London: Routledge.

Coutard, O., \& Rutherford, J. (Eds.). (2015). Beyond the networked city: Infrastructure reconfigurations and urban change in the North and South. London: Routledge.

Cowley, R., \& Caprotti, F. (2019). Smart city as antiplanning in the UK. Environment and Planning D: Society and Space, 37(3), 428-448.

Davidson, K., Coenen, L., Acuto, M., \& Gleeson, B. (2019). Reconfiguring urban governance in an age of rising city networks: A research agenda. Urban Studies, 56(16), 3540-3555.

Evans, J., Karvonen, A., Luque-Ayala, A., Martin, C., McCormick, K., Raven, R., \& Palgan, Y. V. (2019). Smart and sustainable cities? Pipedreams, practicalities and possibilities. Local Environment, 24(7), 557-564.

Evans, J., Karvonen, A., \& Raven, R. (Eds.). (2016). The experimental city. London: Routledge.

Glasmeier, A., \& Christopherson, S. (2015). Thinking about smart cities. Cambridge Journal of Regions, Economy and Society, 8(1), 3-12.

Graham, S. (2001). The city as sociotechnical process: Networked mobilities and urban social inequalities. City, 5(3), 339-349.

Graham, S., \& Marvin, S. (1999). Planning cybercities: Integrating telecommunications into urban planning. Town Planning Review, 70(1), 89-114.

Haarstad, H. (2017). Constructing the sustainable city: Examining the role of sustainability in the 'smart city' discourse. Journal of Environmental Policy \& Planning, 19(4), 423-437.

Hollands, R. G. (2015). Critical interventions into the corporate smart city. Cambridge Journal of Regions, Economy and Society, 8(1), 61-77.

Joss, S., Cook, M., \& Dayot, Y. (2017). Smart cities: Towards a new citizenship regime? A discourse analysis of the British smart city standard. Journal of Urban Technology, 24(4), 29-49.

Kaika, M. (2017). 'Don't call me resilient again!': The New Urban Agenda as immunology...or... what happens when communities refuse to be vaccinated with 'smart cities' and indicators. Environment and Urbanization, 29(1), 89-102.

Karvonen, A. (2018). City of permanent experiments? In B. Turnheim, P. Kivimaa, \& F. Berkhout (Eds.), Innovating climate governance: Moving beyond experiments (pp. 201-215). Cambridge: Cambridge University Press.

Karvonen, A., Cugurullo, F., \& Caprotti, F. (Eds.). (2019). Inside smart cities: Place, politics and urban innovation. London: Routledge.

Kurath, M. M., Marskamp, M., Paulos, J., \& Ruegg, J. (Eds.). (2018). Relational planning: Tracing artefacts, 
agency and practices. London: Palgrave Macmillan.

Lange, K., \& Knieling, J. (2020). Title pending final version. Urban Planning, 8(1), 107-115.

Lee, A., Mackenzie, A., Smith, G. J. D., \& Box, P. (2020). Mapping platform urbanism: Charting the nuance of the platform pivot. Urban Planning, 8(1), 116-128.

Marvin, S., Luque-Ayala, A., \& McFarlane, C. (Eds.). (2015). Smart urbanism: Utopian vision or false dawn? London: Routledge.

Morgan, K., \& Webb, B. (2020). Googling the city: In search of the public interest on Toronto's 'smart' waterfront. Urban Planning, 8(1), 84-95.

Parks, D., \& Rohracher, H. (2019). From sustainable to smart: Re-branding or re-assembling urban energy infrastructure? Geoforum, 100, 51-59.

Rutherford, J. (2020). Redeploying urban infrastructure: The politics of urban socio-technical futures. London: Springer.
Söderström, O., Paasche, T., \& Klauser, F. (2014). Smart cities as corporate storytelling. City, 18(3), 307-320.

Späth, P., \& Knieling, J. (2020). How EU-funded smart city experiments influence modes of planning for mobility: Observations from Hamburg. Urban Transformations, 2(1), 1-17.

Viitanen, J., \& Kingston, R. (2014). Smart cities and green growth: Outsourcing democratic and environmental resilience to the global technology sector. Environment and Planning A, 46(4), 803-819.

Wathne, M. W., \& Haarstad, H. (2020). The smart city as mobile policy: Insights on contemporary urbanism. Geoforum, 108, 130-138.

Yigitcanlar, T., Kamruzzaman, M., Foth, M., SabatiniMarques, J., da Costa, E., \& Ioppolo, G. (2019). Can cities become smart without being sustainable? A systematic review of the literature. Sustainable Cities and Society, 45, 348-365.

\section{About the Authors}
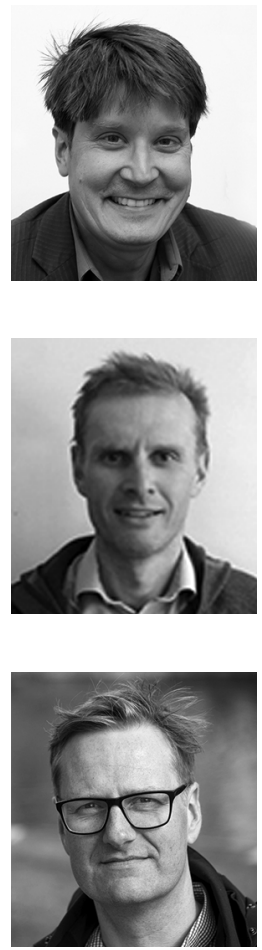

Andrew Karvonen is Associate Professor and Director of Doctoral Studies in the Department of Urban Planning and Environment at the KTH Royal Institute of Technology in Stockholm. He conducts research on the politics and practice of sustainable urban development with a particular focus on infrastructure networks and how they integrate nature, technology, and society. His most recent book, edited with Federico Cugurullo and Federico Caprotti, is Inside Smart Cities: Place, Politics and Urban Innovation (2019, Routledge).

Matthew Cook is Professor of Innovation and leader of the Future Urban Environments research team in the School of Engineering and Innovation at the Open University, UK. Matt's research interests are in innovation and the development of more sustainable urban environments. Working at the intersection of innovation studies and urban studies his work recognises the situatedness of innovation and the inherent spatiality of this complex socio-technical process. Much of Matt's current work is concerned with critical perspectives on the governance of smart city innovations, such as urban energy and transport systems, and the policy mobilities that play a profound role in their (re)construction.

Håvard Haarstad is Professor at the Department of Geography, and Director for the Centre for Climate and Energy Transformation, at the University of Bergen, Norway. In his research, he is broadly interested in sustainability, climate change and energy, particularly in relation to cities. Among other projects, he currently leads the project 'European Cities as Actors in Climate and Energy Transformations', funded by the Trond Mohn Foundation. 